\title{
Deduction at New Media Art with Immateriality in Visual Culture
}

\author{
Changchun Li \\ Dept. of Design \& Art \\ Henan Poly-technic University \\ Zhengzhou, Henan, China. \\ e-mail: 1846903881@qq.com
}

\begin{abstract}
The subsist ability rest with creation and consumption of "content", as tradition element and medium convey way in visual culture at the current time, it also proceed art evolve accommodate modern time, half-sediment status of avianize function in ensemble will be transition step by step, so if ask for immateriality connotation melt in enhance realistic of new media, it need set up framework culture operation way of immateriality social at first, and to extend art zoology space which involved, it cast more perfect value for scriptures culture and art life.
\end{abstract} reality

Keyword-visual culture; new media; immateriality; mix

\section{INTRODUCTION}

Accompanied with media technology development and popularization, what way to continue and protect classics of traditional culture, and display the gorgeous and colorful national art with charm and vitality, that is a main task of Chinese artists and designers faced in current time, and at the same time, it to construct of the context of art visual that it be faced with society tendency of new media with immateriality, the immateriality of art form relates to image of future trend of emergent media. it can be see very clearly from the situation of art verge to immateriality extent from new media in humanity domanial of art and science and technology, which it according to come from information technology and knowledge, and use graphic and sound and etc. multiple as supporter, are provided with seeing and hearing and virtual point with mix space-time imago, it can be more external than formerly figure content creative work and design, it can cover videotape device and multi-media disc and internet art. So that new media art are no longer as a simple aesthetics category, and not the only one like cartoon electric network game fabrication etc. of new media, it collected works such as figure screen age and life installation and zoology landscape synthesize amusement interlink age with commonality of art life of new highland.

\section{IMAGE AT VISUAL CULTURE OF NEW MEDIA}

Art form of new media is of technology with culture, it is transform come from form to non-form and from material to non-material. From 1970's to nowadays, new media and electron new media have been entrance all over the social life, make use of experimental photograph and the interplay of set and network interface, it was given the chance for union about new media with art thinking. With using TV program, new media work of art have a fixedly field, so that it get many electron vasual language, and improve it applied new technology in art creation. Combination of tradition visual art with electron new media that have produce about videotape setting art, which including advantage of new technology and the sensitivity and the Synthetic, and have a living existent and a certain intercommunicate, begin to enter different category of international art exhibition and people's life vision, it also improv non-material experiment and explore. Many main art museum and culture organization of the world have take exhibition about multi-media art, so that can be pushed at the new media art with spread and communication, so like MoMA, Whitney Museum of American Art, Long Beach Museum of Art and World Wild Video-Fest, and so on. At sametime, because of it is have high reality express ability, Digital Animation and Film Special Effects have been applied mostly in visual arts creation field. new media arts industry has had face a new development stage, interact multimedia and 3D technology has waved and standed in the non-matter society, such as in especial at Dinosaur Expo in Japan has a newly method of intermingle present, which can be closed the distance between human and dinosaur, so that let reproduction in exhibition place. it is gave a chance and road for the newly method of intermingle present, such as the sensitivity and the Synthetic, and have a living existant and a certain intercommunicate.

In early 21 th century, 798 which Dashanzi Art District and UCCA in Beijing have been the most active space of mind, which the course for push culture creation and arts industry, and classic design works, enjoy arts bring varied colorful life with audience, put the culture vision to space of present with virtual, and non-matter area, for constructed organize arts about 'Chinese unit', use 'china story' for deduce in broad living space, that it shows the synthetic style such as photographic, web interface, set, virtual place, and so on of visual arts product, include city culture and living space and so on of many theme and direction about future. in exhibition hall and arts store, that it can be have relations with Chinese artist and designer in common to constructed 'organize works of visual'. at the same time, it can be look or receive artist's limited produce at craft works in the independent show space relatively. Art creation are more connect with research into intercourse multi-media and Web works, new media art works 
of china begin on show constantly at the major new media art festival in all over the world, so that it let the art space has get expanded, it is becoming the windsock of culture creation and new media art immateriality trend.

Underneath support of multi-media digitalize technological and transform at visual characteristic in immateriality of new media, from the domain of holographic make picture and digitalize music and digitalize mass media and digitalize amusement, etc. new media have been break through limit of existing technological, have the large degree of freedom in apply expression, and have more broad mix together in internet web. In the later period of 20th century, Daniel Bell had been point out sharply that "culture in the present age is visual sense culture, which it is look upon function of eye as basic way of culture transmission." visual sense art apply achievement experience from immateriality of new media, it hammer at symbol construct with point in the meaning and relevance between them, and span boundary and wide gap of science with art and reason with perceptual and reality with fictitious, and query that fixed pattern of science and art category which setting for, and transcend borderline of one-paneled door, so that it for found out the new situation of visual sense culture and new media arts.

New media arts get through visual image that give it virtual dispose for realize surpass treat substance appearance, so that like malposition and virtual expression are feature of new media. because of art works in the present age are place and circulating at various kinds surroundings space frequently, thus different with tradition arts, it require spectator receive informatization from many angle and more society relevance meaning even relation from works with space-time. New media art form can not stand limit of art category, it can be freely use in synthesize with any device that it could use such as drawing, sculpture, structure, artistic designing, music, drama, poetry, essay, movie, television, record, videotape, photograph, etc. It can be let the people able to unconventional that status suit with works at accept simply, and it can be eliminate people's thinking at appreciate mode in singleness, limited, and briefness. Pass by virtual dispose, the meaning of former finished works that from explicit change into vague with many meaning, limit of beforehand set up from experience reason by transcend, everyday perception of life are perception by feeling and a new lease on life of art, and then will construct perfect and infinite space from limited element.

\section{MIX FRAMEWORK IN MEDIUM OF IMMATERIALITY}

New media of immateriality is a date and information, as well as a immateriality form is based on information, that immateriality relative to matter, so that digitalize society according to knowledge innovate and informationize or is in the service of society that height "immateriality society". Immateriality is not a matter, but it is based on the matter, are objectives real which separate substance from matter and reflect by people's consciousness. When post-industrial period, crux of push visual culture art turn is computer and information technology, new media virtual and immateriality direction image digital that become mix space which with substance surface relative with another spirit will. immateriality in visual art no longer be limited to pay attention to physics design of object, but increasingly emphasize immateriality design such as system, organization structure, intelligentize, interface, atmosphere, interactive, information entertainment and digital technology. People have begin let immateriality regard as a kind of new way of art perceive and culture demand, thus have expand and give new bright spot and appreciation of the beauty interest of immateriality society.

Immateriality of mix reality framework is the aesthetics category in post-modernism philosophy trend of thought influence, at the contemporary era, creative works and appreciation of the beauty process are advocate participation with interaction, the broad masses of the people get involved and experience are indiscerptible a part of art, image which in visual art create or create space are used to tolerate with spectator, to impel spectator from passivity view and admire transform to action of initiative participation at scene which had define. The beautiful state at mix reality where come from empty to true, from true to empty, virtual with real coexist, that agree with dialectical thought and culture consciousness of Chinese classical philosophical which about "theory that man is an integral part of nature" and "All the symbiotic immateriality".

Appreciation of the beauty require spectator in positive thinking and limbs get involved, and still require use other sense organ that consist of vision, auditory sense, touch, sense of smell, even taste sense, so that integration all sense effect in order to revival people's recall in deep and activate mentality sedimentary deposits of culture. Art is the extend of life experiential, make use of matter and culture resource, put to use new media digital units and voice edit and image identification, and etc. in order to construct fictitious support and information interlinking, and it can be put on display the new vision of mix reality art.

Nowadays that the process of people's culture psychology and cognize sentiment have produced obvious transform, art of mix reality in virtual form realm that it can be awaken people's potential consciousness nicely, for inherit history and search culture remember, and make the spirit of art permeate to each corner of life, extend creation space of art form of new media, to framework zoology ideal of art polyphyletic of immateriality society.

\section{VALUE EXPERIENCE OF NEW MEDIA ART}

Deduce of art form in new media is summoned by the concept with singleness and compound at the contemporary era, and also promoted by consumption custom and life-style, so that it have appear posture multielement mixed aspect at form and motive in content attention, theme select, culture motif, art on place, value orientation, emotion direction, and operational approach, etc. new media which pay close attention to reality and future life characteristic in course of approach the view of immateriality society and daily life. Thereof main effect exploration about butt joint and vein among modern visual art and tradition under immateriality context, and grasp innovation bright spot of new media of mix reality under art form, make a thorough inquiry concert information convey with men's cognize and behaviour mutually appropriate, and then carding interface characteristic organization structure digital network of new media 
information, and according to corresponding new media factor proceed innovation of art form.

The emphasis of art idea and form implementation process is noema structure of interactive that people with living space, it give potential value of image at consciousness and receiving, and emphasize mechanism of transmission of new media technology and network. In the circumstances about material products and environmental disruption and wasting of resources at present, it has need rational reflection that extreme consumption and materialization commodity inundate, and look for more humanized criteria of value and artistic concept, so that take advantage of new media can be structure of human landscape of immateriality society which also call forth living principle and psychological pour out, and be going to let traditional culture of nation gene transformation to emptiness with vacant of life rhythm, even enable it reconstruction about humanity homeland.

"living in art up" as a new life meaning that the status feature of contemporary art in economy industry and culture framework. It come to see from the tendency cultural development, that along with evolution of postmodernism thoughts, the subject of value of multi-culture and mixed reality are know as topic for discussion and extend of Postmodernist art, visual culture can be as symbol that surpassing tradition with society limit, it come to make a intelligentized and elegant live lerance. So it stand for psychic imagine can be touch and permeate to art up virtual space, and let national tradition with world culture to come together that common framework about open engine body of immateriality society.

\section{Peroration}

Art form of new media is transition at guide public life-style at first, that make ideal of art permeate in to popular' heart, affiliation context and soul of national, look for new cultural resources and art plane attained that come from immateriality society, use humanistic feelings of art to make good use for image space of visual, and motivate abundant spirit pamper imagination of mankind, and to experience shared linkage of life and art.

\section{REFERENCES}

[1] H.H.Arnason, Histroy of Modern Art, $5^{\text {th }}$ Edition, Prentice Hall, 2003, p.79.

[2] Hal Foster, Art Since 1990: Modernism, Antimodernism, Postmodernism, Thames and Hudson, 2004, p.30.

[3] Michael Archer, Art Since 1960, Thames and Hudson,1997, p.213.

[4] Meggs, A History of Graphic Design, New York: John Wiley \& Sons, inc., 1998, p.187.

[5] Daniel Bell, The Coming of Post-Industrial Society, Harper Collins Publishers, 1973, p.265.

[6] James Elkins, Why Art Cannot Be Tought, Urbara, Chicago,2001, pp.97-98.

[7] Marco Diani, The Immaterial Society, Prentice Hall Inc, 1992. pp.2-3. 